\title{
Effects of metformin on survival outcomes of pancreatic cancer: a meta-analysis
}

\author{
Yi-Wei Dong ${ }^{1, *}$, Yan-Qiang Shi' ${ }^{1, *}$, Li-Wen $\mathrm{He}^{1}$, Xi-Yu Cui ${ }^{2}$ and Pei-Zhu Su ${ }^{2}$ \\ ${ }^{1}$ The Second Clinical Medical School of Southern Medical University, Guangzhou 510282, Guangdong, China \\ ${ }^{2}$ Department of Gastroenterology, The First People's Hospital of Foshan (Affiliated Foshan Hospital of Sun Yat-sen University), \\ Foshan 528000, Guangdong, China \\ *These authors have contributed equally to this work and should be considered as co-first authors \\ Correspondence to: Xi-Yu Cui, email: cuixiyufoshan@126.com \\ Pei-Zhu Su, email: supeizhu1986@163.com
}

Keywords: pancreatic neoplasms, metformin, prognosis, meta-analysis

Received: January 23, $2017 \quad$ Accepted: April 29, $2017 \quad$ Published: May 26, 2017

Copyright: Dong et al. This is an open-access article distributed under the terms of the Creative Commons Attribution License 3.0 (CC BY 3.0), which permits unrestricted use, distribution, and reproduction in any medium, provided the original author and source are credited.

\section{ABSTRACT}

Background and aim: Recent epidemiological studies indicated that metformin might improve the survival of various cancers. However, its benefit on pancreatic cancer was controversial.

Methods: We performed this meta-analysis to investigate the benefit of metformin on pancreatic cancer. A comprehensive literature search was performed through PubMed, Cochrane Library and Embase. Relative risk (RR) and hazard ratio (HR) with 95\% confidence interval (CI) were pooled.

Results: The meta-analysis of 2 randomized controlled trials including 181 pancreatic patients, revealed that metformin use was not associated with an improved overall survival at 6 months $(R R=0.90,95 \% C I=0.67-1.21)$, overall survival $(H R=1.19$, 95\% $\mathrm{CI}=0.86-1.63)$ and progression-free survival $(\mathrm{HR}=1.39,95 \% \mathrm{CI}=0.97-1.99)$. But the meta-analysis of 8 cohorts, involving 2805 pancreatic patients with diabetes, demonstrated a favorable result with improved overall survival ( $H R=0.78,95 \%$ CI=0.66-0.92).

Conclusions: Observations in the cohort studies supported a favorable role of metformin while the data from randomized controlled trials did not support that. Therefore, more high-quality RCTs are warranted.

\section{INTRODUCTION}

Pancreatic cancer is the fourth leading type of cancer death in both male and female in the United States. Despite the improved surgical technique and new chemotherapeutic regimens, the outcome of pancreatic cancer remains poor because of high aggression and treatment resistance. Currently, the overall 5 year survival rate is $7 \%$. And more than half of cases are diagnosed at an advanced stage with unresectable metastatic disease, whose 5 year survival rate is only $4 \%$ [1].

Diabetes mellitus (DM), a worldwide metabolic disorder, is identified as one of strong epidemiological risk factors for pancreatic cancer, besides smoking, age and chronic pancreatitis etc $[2,3]$. The majority of pancreatic cancer patients were diagnosed with either new-onset type 2 diabetes or impaired glucose tolerance $[4,5]$. The mechanism of the association between pancreatic cancer and DM has not been clearly elucidated yet. Evidence shows that hyperinsulinemia, insulin resistance, hyperglycemia, chronic inflammation and elevated circulating insulin-like growth factors causing by DM may promote the cancer growth $[6,7]$. Furthermore, recent epidemic studies and reviews have demonstrated that pancreatic cancer patients with DM might be associated with worse survival than patients without DM [8-10], 
but it is too premature to draw a definitive conclusion. Metformin, a relatively inexpensive and well tolerated oral anti-diabetestic drug for the treatment of T2DM, has raised worldwide attention for its potential anti-tumorigenic effects. The molecule mechanisms of metformin's anticancer activities mostly rely on its ability to inhibit the LKB1-AMPK-mTOR signaling pathway and the cell division, to promote apoptosis and autophagy and downregulate the circulating insulin [11-15]. Therefore, it is reasonable to regard metformin as a potentially effective and safe agent for various cancers. Accumulating evidence has shown that metformin use may be associated with a good prognosis in cancer with diabetes [16-18].

Preliminary studies and reviews have demonstrated that metformin use is correlated with reduced pancreatic cancer risks and improved pancreatic cancer outcomes [19-24]. However, recent randomized controlled trials (RCTs) and one large-scale cohort study showed no existence of such correlation [25-27]. Notably, analysis methods of some studies were criticized due to timerelated bias [28]. Here, we systematically performed a meta-analysis to explore the metformin exposure on the survival in patients with pancreatic cancer.

\section{RESULTS}

\section{Study selection and characteristics}

A total of 858 records were retrieved through databases and other sources (Figure 1). According to the predefined inclusion and exclusion criteria, 2 RCTs, including 144 patients without diabetes and 37 patients with diabetes, and 8 cohorts, including 2805 patients with diabetes were finally included in our meta-analysis [19, 23-27, 29-32]. The main characteristics of the identified studies were summarized in Tables 1 and 2 .

The involving studies were published between 2012 and 2016 with the sample size ranging from 60 to 980 patients. The country where the studies were conducted included Korea $(n=3)$, USA $(n=3)$, United Kingdom $(n=2)$, Italy $(n=1)$ and Netherlands $(n=1)$. HRs were calculated by results of adjusted multivariate analysis except the HR of OS in one cohort and the HR of PFS in another cohort were only available in univariate analysis [24, 32]. The definitions of metformin exposure were reported in 6 cohort studies and the definitions varied across studies. With regard to the quality assessment, the NOS scores of individual cohort studies ranged from 4 to 7 with median of 5.63 and the Jadad scores of two RCTs were 5 and 7 respectively.

\section{Metformin and survival of pancreatic cancer patients in RCTs}

A total of 2 RCTs comprising 181 patients reported HRs for OS at 6 months and PFS [25, 26]. Metformin use was not associated with an improved OS at 6 months $(\mathrm{RR}=0.90,95 \% \mathrm{CI}=0.67-1.21$, Figure 2A) with low heterogeneity $\left(P_{h}=0.763, \mathrm{I}^{2}=0.0 \%\right.$, Figure $\left.2 \mathrm{~A}\right)$, OS $(\mathrm{HR}=1.19,95 \% \mathrm{CI}=0.86-1.63$, Figure $2 \mathrm{~B})$ with low heterogeneity $\left(P_{h}=0.277, \mathrm{I}^{2}=15.3 \%\right.$, Figure $\left.2 \mathrm{~B}\right)$ and PFS $(\mathrm{HR}=1.39,95 \% \mathrm{CI}=0.97-1.99$, Figure $2 \mathrm{C})$ with moderate heterogeneity $\left(P_{h}=0.181, \mathrm{I}^{2}=44.0 \%\right.$, Figure $\left.2 \mathrm{C}\right)$.

\section{Metformin and survival of pancreatic cancer patients in cohort studies}

A total of 8 cohort studies comprising 2805 patients reported HR for OS [19, 23, 24, 27, 29-32]. Metformin use was shown to be beneficial to the increased OS $(\mathrm{HR}=0.78$, $95 \% \mathrm{CI}=0.66-0.92$, Figure 3 ) with moderate heterogeneity $\left(P_{h}=0.017, \mathrm{I}^{2}=58.9 \%\right.$, Figure 3 ). In the subgroup analysis, the HR of Asian countries was $0.70(95 \% \mathrm{CI}=0.60-0.83)$ and the HR of Western countries was $0.84(95 \% \mathrm{CI}=0.67-$ 1.07) (Supplementary Figure 1).

\section{Sensitivity analysis and publication bias of cohort studies}

The leave-one-out analysis revealed that metformin use remained significant with the omission of each individual cohort study in turn. Through calculating the pooled HRs via sensitivity analysis, we found that the study by Hwang et al. contributed to heterogeneity in the meta-analysis of cohort studies [19]. The pooled HRs after exclusion of this study was 0.77 (95\% CI $=0.69$ $\left.0.85, P_{h}=0.236, \mathrm{I}^{2}=25.2 \%\right)$. The pooled HRs $(95 \% \mathrm{CI})$ after adjusting for stage $(n=5)$, performance status $(n=3)$, age $(n=4)$, BMI $(n=3)$, CA19-9 $(n=3)$, resectable cancer $(n=3)$ and advanced cancer $(n=3)$ were $0.78(0.66-0.92)$, 0.69 (0.59-0.80), 0.90 (0.81-1.01), 0.91 (0.81-1.01), $0.69(0.59-0.80), 0.75(0.56-1.00)$ and $0.84(0.62-1.15)$ (Table 3). No obvious publication bias was detected by Begg's funnel plot shape or Egger's test $(p=0.218)$ (Supplementary Figure 2).

\section{DISCUSSION}

This meta-analysis, including 2 RCTs and 8 retrospective cohort studies, comprehensively investigated the effect of metformin on survival outcomes of pancreatic cancer patients. The results of RCTs, which included 144 patients without diabetes and 37 patients with diabetes, were insignificant in OS at 6 months, OS and PFS. Metaanalysis of 8 cohorts including 2805 patients with DM demonstrated significant results that metformin exposure increased the OS. With regard to the pooled HRs for OS, no obvious publication bias existed. Furthermore, the benefit of metformin on OS was still robust across sensitivity analyses except for those including studies adjusted for age, BMI and all estimates for resectable cancer or advanced cancer. 
The results of meta-analysis of retrospective cohorts supported the beneficial effects of metformin exposure on pancreatic cancer patients with diabetes. Metformin inhibited DNA synthesis and proliferation of pancreatic cancer cells close to the desmoplastic reaction by downregulating receptor-PI3K-mTOR signaling pathway [33-36]. By down-regulating vascular endothelial growth factor $b$ signaling pathway, metformin enhances antitumor effects of resveratrol on pancreatic cancers [37]. Additionally, metformin could inhibit the activation of insulin-like growth factor and insulin-like growth factor receptor through the reduction of insulin, and reduce the concentration of insulin receptor substrat 1 to inhibit the PI3K-Akt signaling pathway, which would influence the action of mTOR $[38,39]$. The mitochondrial complex $\mathrm{I}$ is a promising target in cancer cells and the decreased ATP production caused by the inhibition of complex I probably contributes to the anti-tumor effects [40, 41]. Furthermore, metformin would have a therapeutic effect on the metabolic abnormalities caused by diabetes which might have an adverse influence on response to cancer treatments [42].

However, the latest large cohort study and metaanalysis of two RCTs demonstrated different outcomes [25-27]. In the study reported by Reni et al, despite metformin caused endocrine and metabolic modification, the modification was not correlated with favorable PFS at 6 months, PFS, and OS of pancreatic cancer patients.
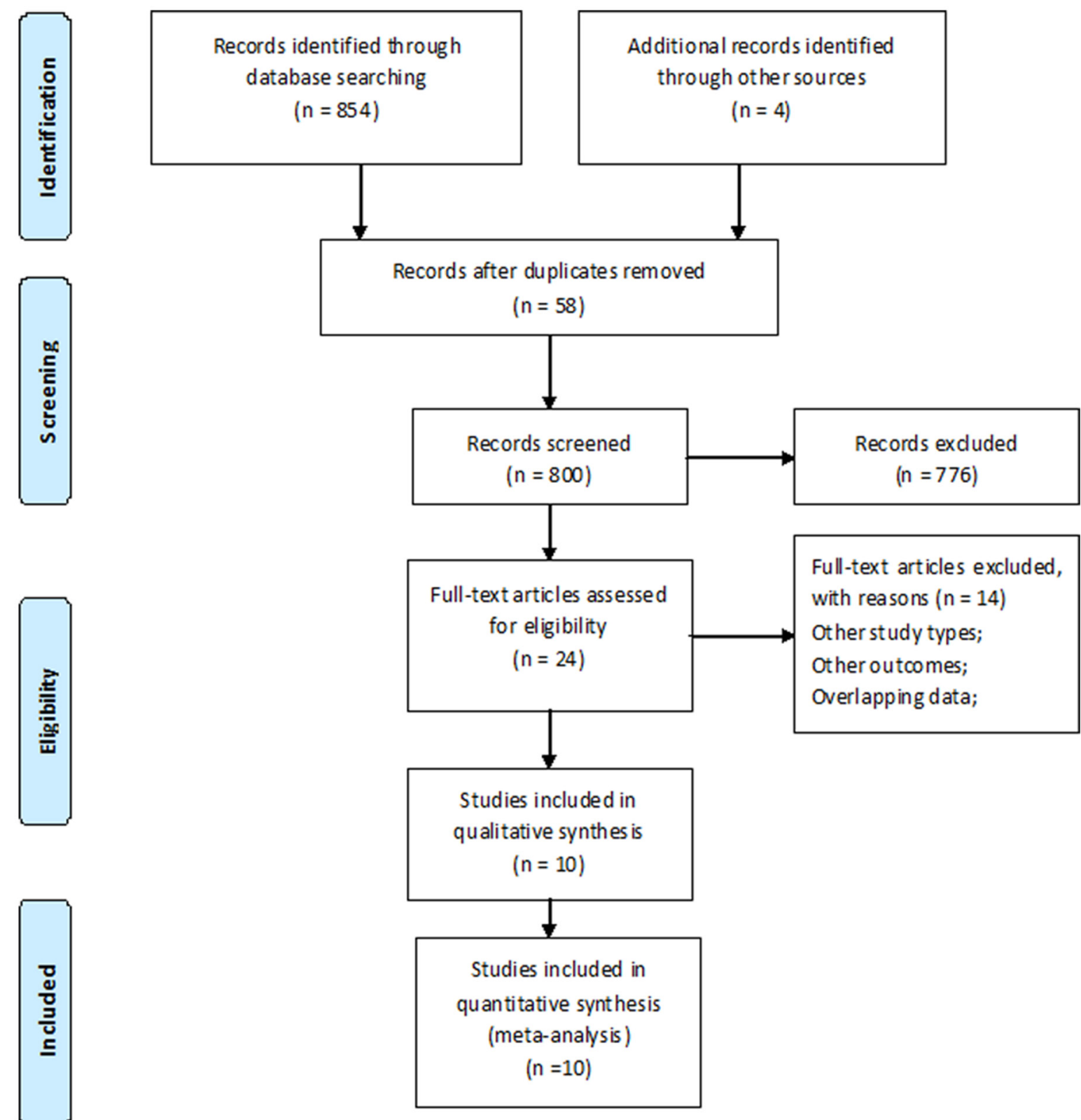

Figure 1: The flow diagram for the included studies. 
Table 1: Characteristics of included cohort studies

\begin{tabular}{|c|c|c|c|c|c|c|c|c|c|}
\hline $\begin{array}{l}\text { Study, year, } \\
\text { country }\end{array}$ & $\begin{array}{l}\text { Definition of } \\
\text { exposure }\end{array}$ & Stage of cancer & Metformin & Nonmetformin & $\begin{array}{l}\text { Median } \\
\text { age } \\
\text { (years) }\end{array}$ & $\begin{array}{l}\text { Survival } \\
\text { analysis }\end{array}$ & Adjusting variables & $\begin{array}{c}\text { Duration and } \\
\text { follow-up (year, } \\
\text { months) }\end{array}$ & $\begin{array}{l}\text { NOS } \\
\text { scores }\end{array}$ \\
\hline $\begin{array}{l}\text { Sadeghi } \\
\text { et al, 2012, } \\
\text { USA. }\end{array}$ & $\begin{array}{l}\text { Ever/never, } \\
\text { regardless of } \\
\text { the dose and } \\
\text { duration of } \\
\text { metformin } \\
\text { use and other } \\
\text { combinational } \\
\text { therapies they } \\
\text { had received. }\end{array}$ & $\begin{array}{l}\text { Resectable(67)/ } \\
\text { unresectable(124) } \\
\text { /metastatic(111) } \\
\text { pancreatic } \\
\text { adenocarcinoma }\end{array}$ & $\begin{array}{l}117 \text { with } \\
\text { pre-cancer } \\
\text { diagnoses of } \\
\text { DM }\end{array}$ & $\begin{array}{l}185 \text { with } \\
\text { pre-cancer } \\
\text { diagnoses of } \\
\text { DM }\end{array}$ & $64.0 \pm 8.7$ & OS & $\begin{array}{l}\text { Disease stage, serum } \\
\text { CA-19-9 level, tumor } \\
\text { size }(\mathrm{cm}), \text { tumor } \\
\text { site(tail), performance } \\
\text { status }\end{array}$ & 2000-2009, 11.4. & 6 \\
\hline $\begin{array}{l}\text { Hwang } \\
\text { et al, } 2013 \text {, } \\
\text { United } \\
\text { Kingdom. }\end{array}$ & $\begin{array}{l}\text { 1. Metformin } \\
\text { use around } \\
\text { the time } \\
\text { of PAC } \\
\text { diagnosis } \\
\text { (between } 6 \\
\text { months prior } \\
\text { and } 1 \text { month } \\
\text { after); } 2 \text {. } \\
\text { Without prior } \\
\text { (i.e., } 6 \text { months } \\
\text { before PAC } \\
\text { diagnosis) } \\
\text { exposure to } \\
\text { metformin }\end{array}$ & $\begin{array}{l}\text { Advanced } \\
\text { pancreatic } \\
\text { adenocarcinoma }\end{array}$ & $\begin{array}{l}247 \text { with } \\
\text { pre-cancer } \\
\text { diagnoses of } \\
\text { DM }\end{array}$ & $\begin{array}{l}269 \text { with } \\
\text { pre-cancer } \\
\text { diagnoses of } \\
\text { DM }\end{array}$ & $72.5 \pm 10$ & OS & $\begin{array}{l}\text { Age, sex, duration of } \\
\text { diabetes, presence of } \\
\text { diabetic complications, } \\
\text { history of pancreatitis, } \\
\text { Charlson index, BMI, } \\
\text { GFR, smoking at the } \\
\text { time of diagnosis, } \\
\text { history of insulin use, } \\
\text { history of sulfonylurea } \\
\text { use, history of } \\
\text { thiazolidinedione use, } \\
\text { and HbA1c }\end{array}$ & 2003-2010, NR. & 6 \\
\hline $\begin{array}{l}\text { Kim et al, } \\
2014, \\
\text { Korea. }\end{array}$ & NR & $\begin{array}{l}\text { Resectable/ } \\
\text { unresectable/ } \\
\text { metastatic(220) }\end{array}$ & $\begin{array}{l}111 \text { with } \\
\text { DM }\end{array}$ & 317 with DM & NR & OS & $\begin{array}{l}\text { ECOG performance } \\
\text { status, CA 19-9, cancer } \\
\text { stage, body mass } \\
\text { index (BMI) and } \\
\text { number of organ } \\
\text { involvement }\end{array}$ & 2005-2010, NR. & 4 \\
\hline $\begin{array}{l}\text { Lee et al, } \\
2015 \text {, } \\
\text { Korea. }\end{array}$ & $\begin{array}{l}\text { Cumulative } \\
\text { duration of } \\
\text { metformin } \\
\text { use at more } \\
\text { than } 1 \\
\text { month after } \\
\text { diagnosis. }\end{array}$ & $\begin{array}{l}\text { Resectable/ } \\
\text { locally advanced/ } \\
\text { metastatic }\end{array}$ & $\begin{array}{l}117 \text { with } \\
\text { pre-cancer } \\
\text { diagnoses of } \\
\text { DM }\end{array}$ & $\begin{array}{l}120 \text { with } \\
\text { pre-cancer } \\
\text { diagnoses of } \\
\text { DM }\end{array}$ & $\begin{array}{c}66 \\
(34-85)\end{array}$ & OS & $\begin{array}{l}\text { ECOG performance } \\
\text { status, tumor size, tail } \\
\text { involvement, CA 19-9 } \\
\text { level, and cancer stage. }\end{array}$ & $2005-2013,10.3$ & 5 \\
\hline $\begin{array}{l}\text { Ambe et al, } \\
2016, \text { USA. }\end{array}$ & $\begin{array}{l}\text { Ongoing use } \\
\text { and never } \\
\text { used }\end{array}$ & $\begin{array}{l}\text { Resectable } \\
\text { pancreatic } \\
\text { adenocarcinoma } \\
\text { cancer }\end{array}$ & $\begin{array}{l}19 \text { with a } \\
\text { preoperative } \\
\text { diagnosis of } \\
\text { DM }\end{array}$ & $\begin{array}{l}25 \text { with a } \\
\text { preoperative } \\
\text { diagnosis of } \\
\text { DM }\end{array}$ & $\begin{array}{c}68 \\
(40-88)\end{array}$ & OS & NR & $1986-2013,19$ & 7 \\
\hline $\begin{array}{l}\text { Kozak et al, } \\
2015, \text { USA. }\end{array}$ & $\begin{array}{l}\text { Continued use } \\
\text { before and } \\
\text { after surgical } \\
\text { resection }\end{array}$ & $\begin{array}{l}\text { Resectable } \\
\text { pancreatic } \\
\text { adenocarcinoma } \\
\text { cancer }\end{array}$ & $\begin{array}{l}13 \text { with a } \\
\text { preoperative } \\
\text { diagnosis of } \\
\text { DM }\end{array}$ & $\begin{array}{l}102 \text { with a } \\
\text { preoperative } \\
\text { diagnosis of } \\
\text { DM }\end{array}$ & $\begin{array}{c}69 \\
(37-86)\end{array}$ & OS, DFS & $\begin{array}{l}\mathrm{N} \text { stage, age, margin } \\
\text { status, adjuvant } \\
\text { radiation, and } \\
\text { gemcitabine }\end{array}$ & $\begin{array}{l}1998-2013, \\
11.23\end{array}$ & 4 \\
\hline $\begin{array}{l}\text { Choi et al, } \\
2016, \\
\text { Korea. }\end{array}$ & NR & $\begin{array}{l}\text { Advanced } \\
\text { pancreatic cancer }\end{array}$ & 56 with DM & $\begin{array}{l}297 \text { (127 with } \\
\text { DM) }\end{array}$ & 59.6 & OS & $\begin{array}{l}\text { All patients: } \\
\text { performance status, } \\
\text { cancer extent and } \\
\text { weight loss during } \\
\text { first-line therapy; DM } \\
\text { subsets: None. }\end{array}$ & 2003-2010, 10.2 & 6 \\
\hline $\begin{array}{l}\text { Chaiteerakij } \\
\text { et al, } 2015 \text {, } \\
\text { United } \\
\text { Kingdom }\end{array}$ & $\begin{array}{l}\text { Different } \\
\text { definitions } \\
\text { of exposure } \\
\text { were } \\
\text { analyzed. }\end{array}$ & $\begin{array}{l}\text { Resectable(284)/ } \\
\text { Locally } \\
\text { advanced(354) } \\
\text { /metastatic }(341) \\
\text { Pancreatic cancer }\end{array}$ & $\begin{array}{l}366 \text { with } \\
\text { DM }\end{array}$ & 614 with DM & 67.4 & OS & $\begin{array}{l}\text { Age, sex, disease } \\
\text { stage, body mass } \\
\text { index, and diagnosis } \\
\text { year group }\end{array}$ & $2000-2011,9.26$ & 7 \\
\hline
\end{tabular}

Abbreviations: DM: diabetes mellitus; NR: not reported; OS: overall survival; DFS: disease-free survival; NOS: Newcastle-Ottawa Scale. 
Table 2: Characteristics of included randomized controlled trials

\begin{tabular}{|c|c|c|c|c|c|c|c|c|c|c|}
\hline Study & $\begin{array}{l}\text { Study } \\
\text { design }\end{array}$ & Intervention & $\begin{array}{l}\text { Stage of } \\
\text { cancer }\end{array}$ & Metformin & Placebo & $\begin{array}{c}\text { Median age } \\
\text { (years) }\end{array}$ & $\begin{array}{l}\text { Survival } \\
\text { analysis }\end{array}$ & $\begin{array}{l}\text { Adjusting } \\
\text { variables }\end{array}$ & $\begin{array}{l}\text { Duration } \\
\text { and } \\
\text { follow- } \\
\text { up (year, } \\
\text { months) }\end{array}$ & $\begin{array}{l}\text { Jada } \\
\text { scores }\end{array}$ \\
\hline $\begin{array}{l}\text { Reni et al, } \\
2015 \text {, Italy. }\end{array}$ & $\begin{array}{l}\text { Open-label, } \\
\text { randomized, } \\
\text { phase II } \\
\text { trial }\end{array}$ & $\begin{array}{l}\text { PEXG every } \\
4 \text { weeks in } \\
\text { combination } \\
\text { or not with } \\
2 \mathrm{~g} \text { oral } \\
\text { metformin } \\
\text { daily }\end{array}$ & $\begin{array}{l}\text { Metastatic } \\
\text { pancreatic } \\
\text { cancer }\end{array}$ & 31 & 29 & $\begin{array}{l}\text { Metformin: } \\
64 \text { (42-75); } \\
\text { Placebo: } \\
63 \text { (44-73). }\end{array}$ & $\begin{array}{l}\text { PFS at } 6 \\
\text { months, } \\
\text { PFS, OS }\end{array}$ & $\begin{array}{l}\text { Age, CA 19- } \\
\text { 9, Karnofsky } \\
\text { performance } \\
\text { status, } \\
\text { lymph nodes } \\
\text { metastasis, } \\
\text { peritoneum } \\
\text { metastasis, } \\
\text { SNP } \\
\text { rs11212617, } \\
\text { adiponectin, } \\
\text { IL-6. }\end{array}$ & $\begin{array}{l}2010- \\
2014, \text { NR. }\end{array}$ & 5 \\
\hline $\begin{array}{l}\text { Kordes et } \\
\text { al, 2015, } \\
\text { Netherlands. }\end{array}$ & $\begin{array}{l}\text { A double- } \\
\text { blind, } \\
\text { randomized, } \\
\text { placebo- } \\
\text { controlled } \\
\text { phase } 2 \text { trial }\end{array}$ & $\begin{array}{l}\text { Received } \\
\text { either oral } \\
\text { metformin } \\
\text { or placebo } \\
\text { twice daily. }\end{array}$ & $\begin{array}{c}\text { Advanced } \\
\text { pancreatic } \\
\text { cancer }\end{array}$ & 60 & 61 & $\begin{array}{l}\text { Metformin: } \\
64 \text { (45-78); } \\
\text { Placebo: } \\
65 \text { (44-79). }\end{array}$ & $\begin{array}{l}\text { OS at } 6 \\
\text { months, } \\
\text { OS, PFS }\end{array}$ & $\begin{array}{c}\text { Tumor stage } \\
\text { and diabetic } \\
\text { state }\end{array}$ & $\begin{array}{l}2010- \\
2014 \\
28.1 \mathrm{~m}\end{array}$ & 7 \\
\hline
\end{tabular}

Abbreviations: NR: not reported; OS: overall survival; PFS: progression-free survival.

(A)

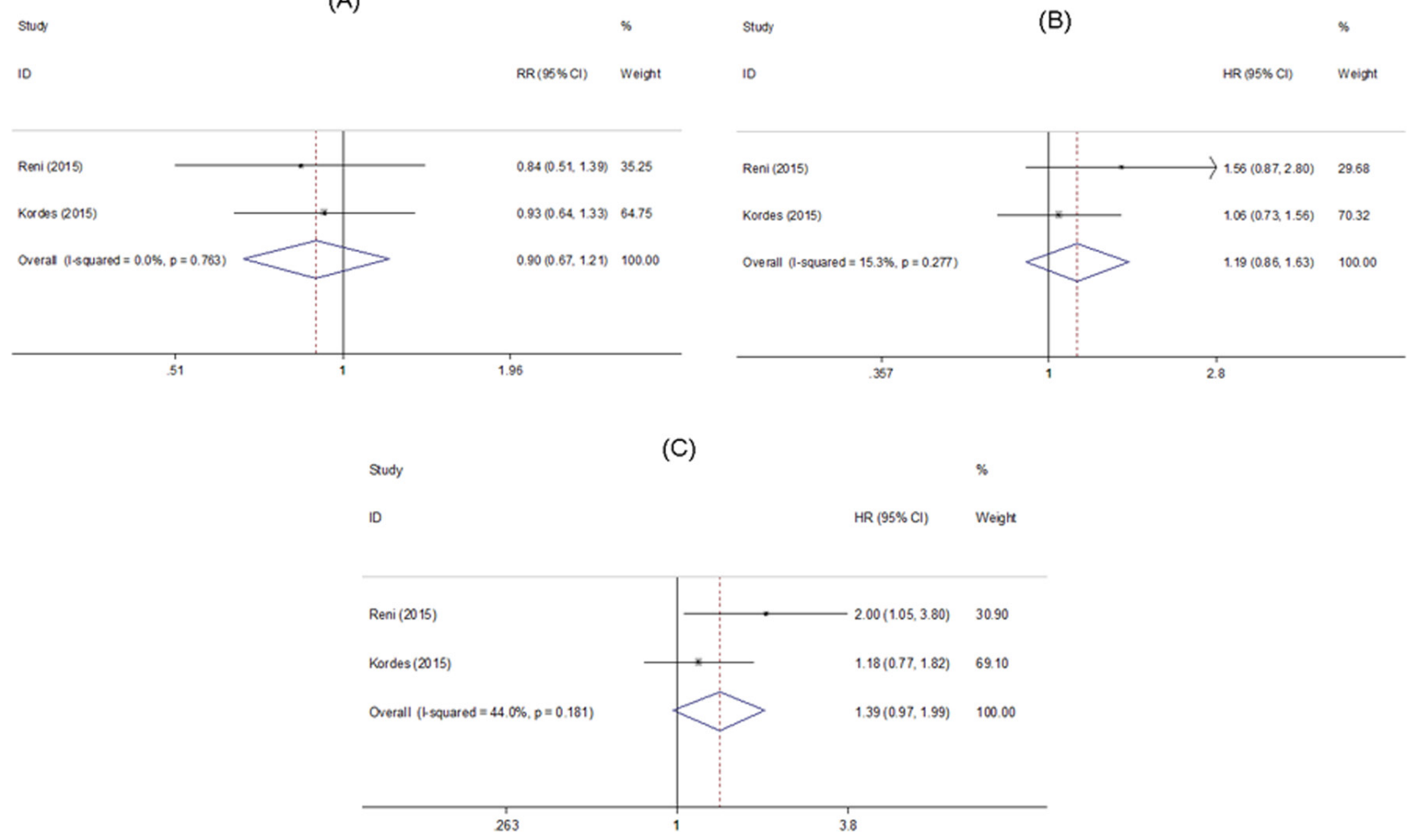

Figure 2: Forest plot of the effect of metformin on pancreatic cancer in randomized controlled trails. HR: hazard ratio; RR: relative risk; CI: confidence interval. (A) Association between metformin effect and overall survival at 6 months; (B) Association between metformin effect and overall survival; (C) Association between metformin effect and progression-free survival. 
Besides, the insulin concentration, insulin receptor expression on tumor tissue and genetic susceptibility to metformin metabolism had no significant correlations with clinical outcomes [25]. In the RCT conducted by Kordes et al, metformin use did not have a statistically significant association with prolongation of survival in pancreatic cancer patients with diabetes, however, metformin use was statistically significantly correlated with survival in patients with locally advanced pancreatic cancer, when stratified by clinical stage [26]. Modest anti-tumor effect and small study sizes may account for ineffectiveness of metformin in advanced pancreatic cancer patients [43]. Besides, RCTs included pancreatic cancer patients with or without diabetes while all the cohorts involved patients with diabetes. RCTs excluded patients with history of using metformin before. As is known, diabetes is a poor prognostic factor for cancer and metformin can control the progression of diabetes. The large cohort of 980 patients with diabetes by Chaiteerakij et al did not find the benefit of metformin use by different definitions of exposure either [27]. Additionally, they illustrated that the different definitions of exposure would have unintended influences on the estimated results, which corresponds to the concerns about time-related biases in the observational studies by Suissa et al [28]. Of interest, they found a statistically significant difference in survival among patients with local advanced cancer. These patients received metformin before cancer diagnosis. This conclusion is similar to the finding of the RCT by Kordes et al [26]. These observations suggest that future trials should focus on the protective effects in patients with locally advanced cancer. The time-biases would come from the time-fixed analysis. Some retrospective studies performed analysis only using a conventional Cox proportional hazards regression model, and most of them suggested beneficial effects of metformin. However, with this analysis, patients were commonly categorized as ever/never use classification and HRs were computed at a specific time, such as the time of diagnosis. The patients who did not receive metformin at the timing but some time after were automatically classified as ever use group. This kind of patients lived long enough to have the chance to receive metformin after previous cancer treatment and their survival time might result from better baseline health other than metformin. Therefore, the ignorance of the timing of initiation probably causes time-related bias and overestimation of metformin effect. To minimize this bias, the time-varying covariate Cox model treated metformin use as time-dependent variables and the patient is not classified in the ever use group until metformin use is initiated.

All in all, several reasons account for the negative result. First, some observational studies were methodologically inaccurate by using a time-fixed analysis

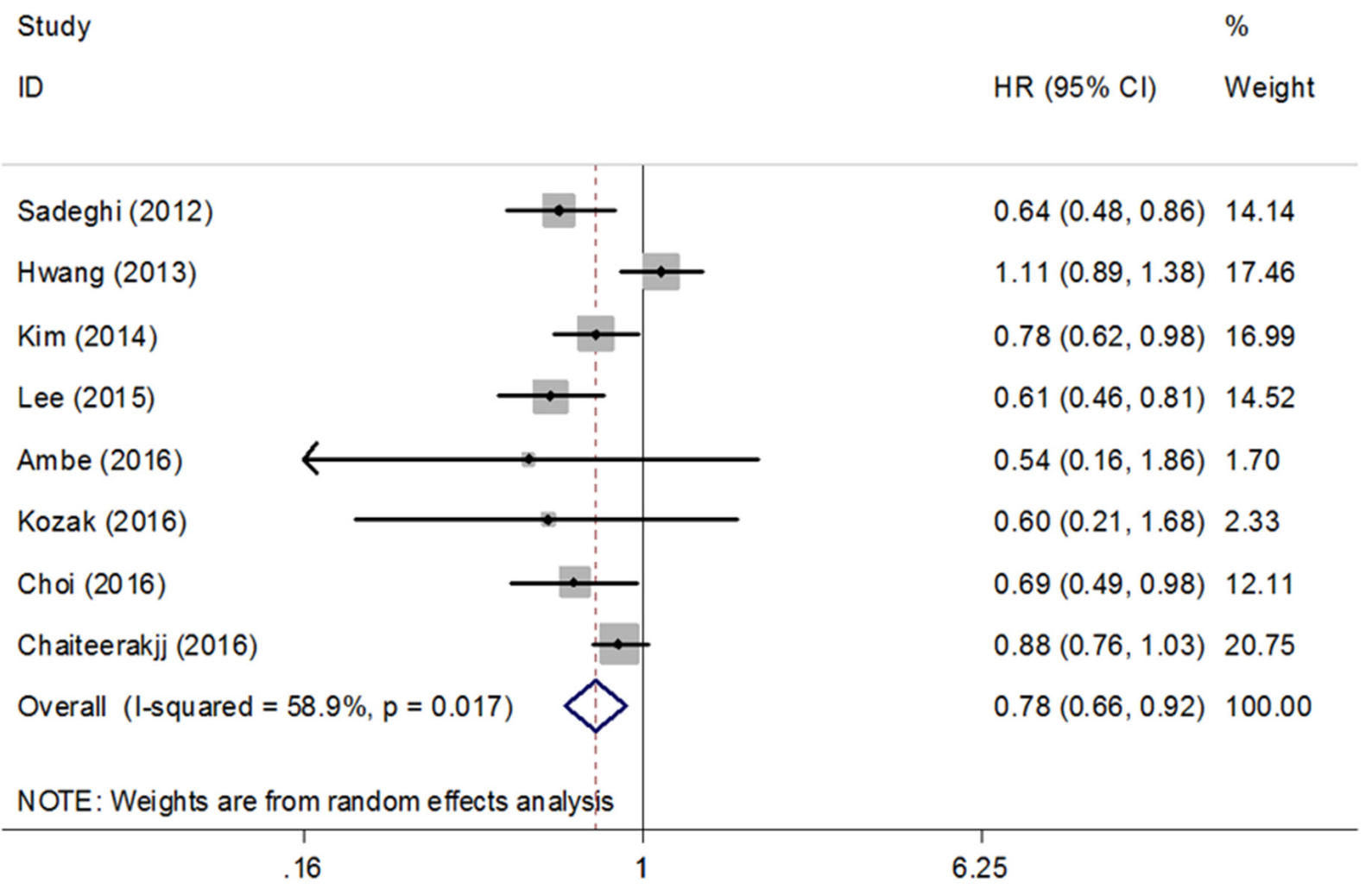

Figure 3: Forest plot of the effect of metformin on overall survival of pancreatic cancer in cohort studies. HR: hazard ratio; CI: confidence interval. 
Table 3: Pooled hazard ratios of overall survival in diabetic pancreatic cancer with and without metformin

\begin{tabular}{|c|c|c|c|c|c|c|c|}
\hline Type of estimate & $\begin{array}{l}\text { Number } \\
\text { of studies }\end{array}$ & Metformin & Nonmetformin & Effects model & $\begin{array}{l}\text { Pooled HR } \\
\text { (95\% CI) }\end{array}$ & $\mathbf{I}^{2}, \%$ & $\begin{array}{c}P \\
\text { value }\end{array}$ \\
\hline All studies & 8 & 1046 & 1759 & Random & $0.78(0.66-0.92)$ & 58.9 & 0.017 \\
\hline Estimates adjusted for stage & 5 & 724 & 1338 & Fixed & $0.78(0.70-0.86)$ & 45.4 & 0.120 \\
\hline $\begin{array}{l}\text { Estimates adjusted for } \\
\text { performance status }\end{array}$ & 3 & 345 & 622 & Fixed & $0.69(0.59-0.80)$ & 4.1 & 0.352 \\
\hline Estimates adjusted for age & 4 & 737 & 1302 & Fixed & $0.90(0.81-1.01)$ & 47.2 & 0.128 \\
\hline Estimates adjusted for BMI & 3 & 724 & 1200 & Fixed & $0.91(0.81-1.01)$ & 60.6 & 0.079 \\
\hline $\begin{array}{l}\text { Estimates adjusted for CA } \\
19-9\end{array}$ & 3 & 345 & 622 & Fixed & $0.69(0.59-0.80)$ & 4.1 & 0.352 \\
\hline $\begin{array}{l}\text { All estimates for resectable } \\
\text { cancer }\end{array}$ & 3 & 129 & 314 & Fixed & $0.75(0.56-1.00)$ & 0.0 & 0.773 \\
\hline $\begin{array}{l}\text { All estimates for advanced } \\
\text { cancer }\end{array}$ & 3 & 435 & 618 & Random & $0.84(0.62-1.15)$ & 74.8 & 0.019 \\
\hline
\end{tabular}

Abbreviations: CI: confidence interval; HR: hazard ratio; BMI: body mass index.

and would lead to overestimation of metformin effects for pancreatic cancer patients. Second, the metformin might be beneficial to pancreatic cancer patients with diabetes rather than pancreatic cancer patients without diabetes, and the hypothetical anti-neoplastic activity might be probably based on the concurrent diabetes. Third, the heterogeneity in cancer stage might contribute to the discrepancies in findings between RCTs and cohort studies. Among 8 cohort studies, six studies included patients in resectable cancer stage. However, the two RCTs were conducted in late stage patients, such as metastatic and advanced cancer. Forth, as for the molecule mechanism, although in vitro experiments showed anti-neoplastic activities of metformin on cancer cells, the concentration in patient's neoplastic tissue fail to achieve a level as stable and sufficient as it in cells to cause energetic action [44]. As an anti-cancer agent, maybe metformin with a higher dose than the anti-diabetic dose is required. Additionally, metformin would have potential antagonism effect against chemotherapy [45]. Metformin acting cell autonomously can either increase or decrease reactive oxygen species generation through which most of chemotherapeutic drugs work.

Several limitations in this meta-analysis need to be considered. First, the administration of metformin exposure, including dosage, duration and timing of metformin initiation, were varied across included studies. However, relevant sensitivity analysis was not conducted due to the limited data. Second, the different characteristics of pancreatic cancer, including pathological types, tumor size and clinical stages, would contribute to high heterogeneity. Third, therapeutic schedules for pancreatic cancer and their effects on survival were not described clearly, which would affect estimations of metformin on cancer survival. Fourth, only one study adjusted the use of other anti-diabetic drugs including sulfonylureas and insulin, which might result in underestimation of benefits of metformin [19]. Fifth, we were supposed to extract multivariate HR to minimize the effects of confounders. However, we selected the univariate HR rather than multivariate HR in some special occasions. The univariate HR of OS was selected from the study by Choi et al, because the multivariate HR was for all patients while the univariate HR was for diabetes patients only and the latter was what we needed according to our aim [24]. Additionally, the univariate HR of PFS was chosen in study by Kozak et al because of the lack of precise multivariate HR [32]. Although sensitivity analyses were conducted in accordance with adjusted variables, the number of studies included in each sensitivity analysis was small and probably contributed to overestimation and underestimation of the treatment effects. Sixth, one abstract was included in our meta-analysis in order to obtain adequate survival information, while the details of the baseline and outcome were unavailable [29]. Seventh, our meta-analyses were based on summarized data rather than data from individuals, which might result in overestimation of treatment effects.

With regard to the association between metformin and the outcome of pancreatic cancer patients with diabetes, whether patients were exposed to metformin before cancer diagnosis requires attention. The RCT of Kordes et al showed patients who achieved a decrease in insulin concentrations in the metformin group had improved survival than those who did not achieve decreased insulin [26]. However, insulin reductions in the placebo group were not associated with a survival benefit, indicating that whether the insulin level are associated with 
metformin effects warrants further studies. In addition, more pharmacodynamic assessments of metformin effects on mitochondrial glycolytic metabolic function should be explored in future researches, such as insulin receptors and the organic cation transporters.

In conclusion, our meta-analyses showed that observations in the cohort studies supported a favorable anti-cancer role of metformin while data from RCTs did not support this role. Additionally, metformin exposure might benefit pancreatic cancer patients with concurrent diabetes. To determine the effect of metformin on survival after pancreatic cancer diagnosis, more high-quality RCTs are warranted.

\section{MATERIALS AND METHODS}

\section{Literature research}

This meta-analysis follows PRISMA guidelines (Supplementary File 3) [46]. PubMed, Cochrane Library and Embase were systematically searched up with search strategies based on following terms used in PubMed: ("Metformin"[Mesh] OR (metformin OR biguanides OR "hypoglycemic agents")) AND ("Pancreatic Neoplasms"[Mesh] OR ((pancreatic OR pancreas) AND (neoplasms OR cancer OR carcinoma))) AND ("Prognosis/mortality"[Mesh] OR (prognosis OR prognostic OR outcome OR survival OR mortality)). Any restriction including language, human research or study design was not permitted. Besides, manual searching of references in identified studies and relevant reviews was conducted to retrieve every potential article.

\section{Inclusion/exclusion criteria}

Two authors independently reviewed the candidate studies, and discrepancies were resolved by discussion. We selected eligible studies according to the predefined inclusion and exclusion criteria. Inclusion criteria were: (1) RCTs or cohort studies with controlled group; (2) studies investigating the association between metformin use and the prognosis of pancreatic cancer patients; (3) analysis of survival outcome including overall survival (OS) or progress-free survival (PFS); (4) sufficient information to estimate relative risk (RR) and hazard ratio (HR) with 95\% confidence interval (95\% CI). Exclusion criteria were: (1) study types including case report, review, case series, editorial and letter; (2) studies without sufficient data to estimate RR or HR with related 95\% CI; (3) language other than Chinese and English; (4) nonhuman researches.

\section{Data extraction and quality assessment}

Data of identified studies was extracted by two investigators independently. The latest study with more abundant data was included in meta-analysis when the data overlapped cross studies. The following information was extracted: author, year of publication, country of study, definition of exposure or intervention, sample size, age, survival analysis, adjusting variables, duration, followup and data of survival analyses. If several estimations were conducted in one study, the most powerful result was selected (i.e., the multivariate regression will be given priority, and the univariate regression was superior to the unadjusted Kaplan-Meier analysis). If several definitions of exposure or population were reported in one study, data from the definition which was more similar to the remaining studies was extracted and other data was collected for sensitivity analyses. The quality assessments were applied using the Newcastle-Ottawa Quality Assessment Scale (NOS) for cohort studies and Jadad scale for RCTs by two reviewers independently $[47,48]$. Discrepancies were discussed and resolved in the process.

\section{Statistical analysis}

RRs and HRs along with their 95\% CIs were gained directly from included studies or from estimation based on methods by Parmer et al, resulting in a conservative estimate of the significance level [49]. The significance of the pooled HR and RR were determined by Z-test, and the level of statistical significance was established as $P<0.05$ [50]. The heterogeneity among studies was checked by the Q test and Higgins I-squared statistic [50, 51]. The MantelHaenszel method based on fixed effects model would be performed to calculate the pooled HRs on the condition that $P$ value for the heterogeneity test was greater than 0.05 [52]. Otherwise, the random effects model based on DerSimonian and Laird method would be used [53]. The sensitivity analysis was conducted by omitting individual studies. Furthermore, considering the variations in the covariates, we conducted sensitivity analyses by calculating pooled HRs with estimates adjusted for certain confounders, including stage, performance status, age, body mass index (BMI) and CA 19-9. Sensitivity analyses were also conducted in all estimates for resectable cancer and advanced cancer. Publication bias was evaluated by Begg's funnel plot and Egger's test $(P<0.05$ was considered a significant publication bias) $[54,55]$. The meta-analyses were performed using Stata version 12.0 software (Stata, College Station, TX, USA).

\section{ACKNOWLEDGMENTS}

None.

\section{CONFLICTS OF INTEREST}

The authors declare no conflicts of interest. 


\section{FUNDING}

Grant sponsor: Science and Technology Planning Project of Guangdong Province, China; Grant number: 2016A020215110.

\section{REFERENCES}

1. Siegel RL, Miller KD, Jemal A. Cancer statistics, 2015. CA Cancer J Clin. 2015; 65:5-29.

2. Haugvik SP, Hedenstrom P, Korsaeth E, Valente R, Hayes A, Siuka D, Maisonneuve P, Gladhaug IP, Lindkvist B, Capurso G. Diabetes, smoking, alcohol use, and family history of cancer as risk factors for pancreatic neuroendocrine tumors: a systematic review and metaanalysis. Neuroendocrinology. 2015; 101:133-142.

3. Chari ST, Kelly K, Hollingsworth MA, Thayer SP, Ahlquist DA, Andersen DK, Batra SK, Brentnall TA, Canto M, Cleeter DF, Firpo MA, Gambhir SS, Go VL, et al. Early detection of sporadic pancreatic cancer: summative review. Pancreas. 2015; 44: 693-712.

4. Bojkova B, Orendas P, Garajova M, Kassayova M, Kutna V, Ahlersova E, Ahlers I. Metformin in chemically-induced mammary carcinogenesis in rats. Neoplasma. 2009; 56: 269-274.

5. Anisimov VN, Berstein LM, Popovich IG, Zabezhinski MA, Egormin PA, Piskunova TS, Semenchenko AV, Tyndyk ML, Yurova MN, Kovalenko IG, Poroshina TE. If started early in life, metformin treatment increases life span and postpones tumors in female SHR mice. Aging (Albany NY). 2011; 3: 148-157. doi: 10.18632/ aging. 100273 .

6. Biadgo B, Abebe M. Type 2 diabetes mellitus and its association with the risk of pancreatic carcinogenesis: a review. Korean J Gastroenterol. 2016; 67:168-177.

7. Meier JJ, Giese A. Diabetes associated with pancreatic diseases. Curr Opin Gastroenterol. 2015; 31: 400-406.

8. Shen H, Zhan M, Wang W, Yang D, Wang J. Impact of diabetes mellitus on the survival of pancreatic cancer: a meta-analysis. Onco Targets Ther. 2016; 9: 1679-1688.

9. Fedeli U, Zoppini G, Gennaro N, Saugo M. Diabetes and cancer mortality: a multifaceted association. Diabetes Res Clin Pract. 2014; 106:e86-89.

10. Raghavan SR, Ballehaninna UK, Chamberlain RS. The impact of perioperative blood glucose levels on pancreatic cancer prognosis and surgical outcomes: an evidence-based review. Pancreas. 2013; 42:1210-1217.

11. Kisfalvi K, Eibl G, Sinnett-Smith J, Rozengurt E. Metformin disrupts crosstalk between G protein-coupled receptor and insulin receptor signaling systems and inhibits pancreatic cancer growth. Cancer Res. 2009; 69: 6539-6545.
12. Dowling RJ, Zakikhani M, Fantus IG, Pollak M, Sonenberg N. Metformin inhibits mammalian target of rapamycindependent translation initiation in breast cancer cells. Cancer Res. 2007; 67:10804-10812.

13. Gotlieb WH, Saumet J, Beauchamp MC, Gu J, Lau S, Pollak MN, Bruchim I. In vitro metformin anti-neoplastic activity in epithelial ovarian cancer. Gynecol Oncol. 2008; 110:246-250.

14. Simbulan-Rosenthal CM, Rosenthal DS, Iyer S, Boulares AH, Smulson ME. Transient poly(ADP-ribosyl)ation of nuclear proteins and role of poly(ADP-ribose) polymerase in the early stages of apoptosis. J Biol Chem. 1998; 273:13703-13712.

15. Morran DC, Wu J, Jamieson NB, Mrowinska A, Kalna G, Karim SA, Au AY, Scarlett CJ, Chang DK, Pajak MZ, Australian Pancreatic Cancer Genome I, Oien KA, McKay $\mathrm{CJ}$, et al. Targeting mTOR dependency in pancreatic cancer. Gut. 2014; 63: 1481-1489.

16. Zhang P, Li H, Tan X, Chen L, Wang S. Association of metformin use with cancer incidence and mortality: a metaanalysis. Cancer Epidemiol. 2013; 37:207-218.

17. Xu H, Chen K, Jia X, Tian Y, Dai Y, Li D, Xie J, Tao M, Mao Y. Metformin use is associated with better survival of breast cancer patients with diabetes: a meta-analysis. Oncologist. 2015; 20:1236-1244.

18. Lega IC, Shah PS, Margel D, Beyene J, Rochon PA, Lipscombe LL. The effect of metformin on mortality following cancer among patients with diabetes. Cancer Epidemiol Biomarkers Prev. 2014; 23: 1974-1984.

19. Hwang AL, Haynes K, Hwang WT, Yang YX. Metformin and survival in pancreatic cancer: a retrospective cohort study. Pancreas. 2013; 42:1054-1059.

20. Lee MS, Hsu CC, Wahlqvist ML, Tsai HN, Chang YH, Huang YC. Type 2 diabetes increases and metformin reduces total, colorectal, liver and pancreatic cancer incidences in Taiwanese: a representative population prospective cohort study of 800,000 individuals. BMC Cancer. 2011; 11:20.

21. Li D, Yeung SC, Hassan MM, Konopleva M, Abbruzzese JL. Antidiabetic therapies affect risk of pancreatic cancer. Gastroenterology. 2009; 137:482-488.

22. Wang Z, Lai ST, Xie L, Zhao JD, Ma NY, Zhu J, Ren ZG, Jiang GL. Metformin is associated with reduced risk of pancreatic cancer in patients with type 2 diabetes mellitus: a systematic review and meta-analysis. Diabetes Res Clin Pract. 2014; 106:19-26.

23. Sadeghi N, Abbruzzese JL, Yeung SC, Hassan M, Li D. Metformin use is associated with better survival of diabetic patients with pancreatic cancer. Clin Cancer Res. 2012; 18:2905-2912.

24. Choi Y, Kim TY, Oh DY, Lee KH, Han SW, Im SA, Kim TY, Bang YJ. The impact of diabetes mellitus and 
metformin treatment on survival of patients with advanced pancreatic cancer undergoing chemotherapy. Cancer Res Treat. 2016; 48:171-179.

25. Reni M, Dugnani E, Cereda S, Belli C, Balzano G, Nicoletti R, Liberati D, Pasquale V, Scavini M, Maggiora P, Sordi V, Lampasona V, Ceraulo D, et al. (Ir)relevance of metformin treatment in patients with metastatic pancreatic cancer: an open-label, randomized Phase II Trial. Clin Cancer Res. 2016; 22:1076-1085.

26. Kordes S, Pollak MN, Zwinderman AH, Mathot RA, Weterman MJ, Beeker A, Punt CJ, Richel DJ, Wilmink JW. Metformin in patients with advanced pancreatic cancer: a double-blind, randomised, placebo-controlled phase 2 trial. Lancet Oncol. 2015; 16:839-847.

27. Chaiteerakij R, Petersen GM, Bamlet WR, Chaffee KG, Zhen DB, Burch PA, Leof ER, Roberts LR, Oberg AL. Metformin use and survival of patients with pancreatic cancer: a cautionary lesson. J Clin Oncol. 2016; 34:1898-1904.

28. Suissa S, Azoulay L. Metformin and the risk of cancer: time-related biases in observational studies. Diabetes Care. 2012; 35:2665-2673.

29. Kim SH, Kim MH, Kang B, Ahn JB, Choi HJ. 699p metformin use is associated with improved survival in diabetic pancreatic cancer patients. Ann Oncol. 2014; 25: iv238.

30. Lee SH, Yoon SH, Lee HS, Chung MJ, Park JY, Park SW, Song SY, Chung JB, Bang S. Can metformin change the prognosis of pancreatic cancer? Retrospective study for pancreatic cancer patients with pre-existing diabetes mellitus type 2. Dig Liver Dis. 2016; 48:435-440.

31. Ambe CM, Mahipal A, Fulp J, Chen L, Malafa MP. Effect of metformin use on survival in resectable pancreatic cancer: a single-institution experience and review of the literature. PLoS One. 2016; 11:e0151632.

32. Kozak MM, Anderson EM, von Eyben R, Pai JS, Poultsides GA, Visser BC, Norton JA, Koong AC, Chang DT. Statin and metformin use prolongs survival in patients with resectable pancreatic cancer. Pancreas. 2016; 45:64-70.

33. Forcet C, Billaud M. Dialogue between LKB1 and AMPK: a hot topic at the cellular pole. Sci STKE. 2007; 2007:pe51.

34. Pollak MN. Investigating metformin for cancer prevention and treatment: the end of the beginning. Cancer Discov. 2012; 2:778-790.

35. Pollak M. Overcoming drug development bottlenecks with repurposing: repurposing biguanides to target energy metabolism for cancer treatment. Nat Med. 2014; 20:591-593.

36. Zechner D, Burtin F, Albert AC, Zhang X, Kumstel S, Schonrogge M, Graffunder J, Shih HY, Muller S, Radecke
T, Jaster R, Vollmar B. Intratumoral heterogeneity of the therapeutical response to gemcitabine and metformin. Oncotarget. 2016; 7:56395-56407. doi: 10.18632/ oncotarget.10892.

37. Zhu M, Zhang Q, Wang X, Kang L, Yang Y, Liu Y, Yang L, Li J, Yang L, Liu J, Li Y, Zu L, Shen Y, Qi Z. Metformin potentiates anti-tumor effect of resveratrol on pancreatic cancer by down-regulation of VEGF-B signaling pathway. Oncotarget. 2016; 7:84190-84200. doi: 10.18632/ oncotarget.12391.

38. Pollak MN, Schernhammer ES, Hankinson SE. Insulinlike growth factors and neoplasia. Nat Rev Cancer. 2004; 4:505-518.

39. Karnevi E, Said K, Andersson R, Rosendahl AH. Metformin-mediated growth inhibition involves suppression of the IGF-I receptor signalling pathway in human pancreatic cancer cells. BMC Cancer. 2013; 13: 235.

40. Wheaton WW, Weinberg SE, Hamanaka RB, Soberanes S, Sullivan LB, Anso E, Glasauer A, Dufour E, Mutlu GM, Budigner GS, Chandel NS. Metformin inhibits mitochondrial complex I of cancer cells to reduce tumorigenesis. eLife. 2014; 3:e02242.

41. Cohen R, Neuzillet C, Tijeras-Raballand A, Faivre S, de Gramont A, Raymond E. Targeting cancer cell metabolism in pancreatic adenocarcinoma. Oncotarget. 2015; 6: 1683216847. doi: 10.18632/oncotarget.4160.

42. Richardson LC, Pollack LA. Therapy insight: influence of type 2 diabetes on the development, treatment and outcomes of cancer. Nat Clin Pract Oncol. 2005; 2:48-53.

43. Jang WI, Kim MS, Kang SH, Jo AJ, Kim YJ, Tchoe HJ, Park CM, Kim HJ, Choi JA, Choi HJ, Paik EK, Seo YS, Yoo HJ, et al. Association between metformin use and mortality in patients with type 2 diabetes mellitus and localized resectable pancreatic cancer: a nationwide population-based study in korea. Oncotarget. 2017; 8:95879596. doi: 10.18632/oncotarget.14525.

44. Gou S, Cui P, Li X, Shi P, Liu T, Wang C. Low concentrations of metformin selectively inhibit CD133(+) cell proliferation in pancreatic cancer and have anticancer action. PLoS One. 2013; 8:e63969.

45. Chandel N. Four key questions about metformin and cancer. BMC Biol. 2014; 12:85.

46. Moher D, Liberati A, Tetzlaff J, Altman DG. Preferred reporting items for systematic reviews and meta-analyses: the PRISMA statement. PLoS Med. 2009; 6:e1000097.

47. Jadad AR, Moore RA, Carroll D, Jenkinson C, Reynolds DJ, Gavaghan DJ, McQuay HJ. Assessing the quality of reports of randomized clinical trials: is blinding necessary? Control Clin Trials. 1996; 17:1-12.

48. GA Wells BS, D O'Connell, J Peterson, V Welch, M Losos, P Tugwell. The Newcastle-Ottawa Scale (NOS) 
for assessing the quality of nonrandomised studies in meta-analyses. Available at: http://wwwohrica/programs/ clinical_epidemiology/oxfordasp (accessed 8 August 2014).

49. Parmar MK, Torri V, Stewart L. Extracting summary statistics to perform meta-analyses of the published literature for survival endpoints. Stat Med. 1998; 17:2815-2834.

50. Cochran WG. The Combination of Estimates from Different Experiments. Biometrics. 1954; 10:101-129.

51. Higgins JP, Thompson SG, Deeks JJ, Altman DG. Measuring inconsistency in meta-analyses. BMJ. 2003; 327: $557-560$.
52. Mantel N, Haenszel W. Statistical aspects of the analysis of data from retrospective studies of disease. J Natl Cancer Inst. 1959; 22:719-748.

53. DerSimonian R, Laird N. Meta-analysis in clinical trials. Control Clin Trials. 1986; 7:177-188.

54. Egger M, Davey Smith G, Schneider M, Minder C. Bias in meta-analysis detected by a simple, graphical test. BMJ. 1997; 315:629-634.

55. Begg CB, Mazumdar M. Operating characteristics of a rank correlation test for publication bias. Biometrics. 1994; 50: 1088-1101. 